\title{
Students' Exploratory Analysis Study of Internet Skills
}

\author{
Loliyana ${ }^{1, *}$, Ismu Sukamto ${ }^{2}$ \\ Pendidikan Guru Sekolah Dasar, Universitas Lampung, Jl. Prof. Dr. Ir. Sumantri Brojonegoro, Bandar Lampung, 35141 Indonesia \\ ${ }^{1}$ ismu.sukamto1101@fkip.unila.ac.id \\ * corresponding author
}

\begin{abstract}
ARTICLE INFO ABSTRACT
Article history

Received August 10, 2020

Revised Dec 19, 2020

Accepted Dec 19, 2020

Keywords

Internet skills

Student

The purpose of this study was to describe the internet skills of students. The method used was a survey with an exploratory research design. The research sample consisted of 166 students. The research instrument was adapted (Van Deursen et al., 2016) which is composed of 5 indicators, namely: (1) operational internal skills; (2) formal internet skills; (3) informational internet skills; (4) communicational internet skills; and (5) content creation internet skills. The results showed that students had good internet skills, including operational, formal, communicational, and informational skills. Nevertheless, it was necessary to develop creative skills so that students are more productive in creating or developing content in a digital environment. In addition, there was a positive relationship between operational and communicational skills and con-tent creation skills. Thus, it can be concluded that overall, students have good basic internet skills. However, further research is needed to find out how these variables affect other variables.

Tujuan penelitian ini adalah untuk mendeksripsikan keterampilan internet mahasiswa. Metode yang digunakan adalah survei dengan desain penelitian eksploratori. Sampel penelitian maha-siswa yang berjumlah 166 orang. Instrumen penelitian diadaptasi dari instrumen yang dikembangkan oleh (Van Deursen et al., 2016) yang tersusun atas 5 indikator, yaitu: (1) ket-erampilan interner operasional; (2) keterampilan internet formal; (3) keterampilan internet in-formasional; (4) keterampilan internet komunikasional; dan (5) keterampilan internet kreasi kon-ten. Hasil penelitian menunjukkan bahwa mahasiswa memiliki keterampilan internet yang baik, meliputi keterampilan internet operasional, formal, komunikasional dan informasional. Namun, keterampilan internet kreasi konten mahasiswa masih tergolong rendah. Selain itu, terdapat hubungan positif antara keterampilan operasional dan komunikasional dengan keterampilan kreasi konten. Dengan demikian, secara keseluruhan mahasiswa sesungguhnya sudah memiliki keterampilan internet dasar yang baik.
\end{abstract}

This is an open access article under the $\mathrm{CC}-\mathrm{BY}$ license.

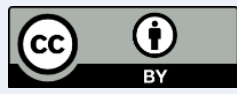

\section{Introduction}

Internet has become a human need in all fields to support life activities. Likewise, in the field of education, where the use of the internet is very much needed, such as opening a browser (Bunz et al., 2007; Hargittai \& Hsieh, 2012; Krueger, 2006; Potosky, 2007) to find information both in the search for teaching materials and those related to learning mechanisms. With the help of the internet in online learning, students' understanding of learning materials increases higher than using only face-to-face learning (Kuntarto, 2017). However, this increase should be optimized again if the lecturer understands students' internet skills. By knowing these skills, lecturers can determine the appropriate online learning methods and media according to their characteristics.
Furthermore, lecturers can also facilitate students to improve their internet skills, which are important skills to master in today's digital era.

Thus, digitalization in learning can run as expected, where students understand how to act both in the operational aspects of using the internet both through computer and mobile devices, navigation aspects in searching for information or learning materials, social aspects of communication in a digital environment or aspects of creativity in making digital information. These four aspects are the basic abilities that students must have in a digital environment. With these abilities, students can operate the internet to explore looking for the data needed in various forms (text, images, videos, simulations, and the like) and take advantage of the online content. (Alkali \& 
Amichai-Hamburger, 2004; Bawden, 2008; Brandtweiner et al., 2010; Ferrari, 2012). These various forms of information allow students to think creatively, create or develop different forms of in-formation to be shared in a digital social environment, where there is a combination of communication and socioemotional required. (Alkali \& Amichai-Hamburger, 2004; Calvani et al., 2012; Haythornthwaite, 2007; Helsper \& Eynon, 2013)

Therefore, it is necessary to have an accurate mechanism in describing these abilities so that this empirical work is represented as a reference for providing appropriate treatment. The steps used also reflect current theoretical thinking and keep pace with changes in the way academics use and understand the internet. The instruments he uses must also be able to measure the skills an individual has, how this is related to certain types of involvement and how this can then impact on more specific aspects of learning. In the end, the data obtained form the basis for developing a better model of online learning.

The development of digital activity instruments considers accessibility, skills, attitudes or motivation, relevance, quality, ownership, the purpose of using the internet and the tangible results that have been achieved. Thus, the characteristics of the net learners can be described in depth. Therefore, the purpose of this study is to describe students' internet skills.

\section{Method}

This study used an exploratory research design (Žukauskas et al., 2018) to find out student skills. Considering that the problems to be studied have similarities in certain fields of study, the sampling technique was carried out purposively (for certain purposes), where the research sample consisted of 166 students in Semester I, III, V and VII. In detail, it can be seen in Table 1 .

Table 1. Research sample profile

\begin{tabular}{cccc}
\hline No & Semester Students to- & $\mathbf{N}$ & $\boldsymbol{\%}$ \\
\hline 1 & 1 & 100 & 60,24 \\
2 & 3 & 29 & 17,47 \\
3 & 5 & 27 & 16,27 \\
4 & 7 & 10 & 6,02 \\
& Total & 166 & $100 \%$ \\
\hline
\end{tabular}

We distributed the instruments online to all students. However, not all students gave their responses to the given instrument. This study used an instrument developed by (Van Deursen et al., 2016), which is composed of 5 indicators, namely: (1) operational internet skills; (2) formal internet skills; (3) informational internet skills; (4) communicational internet skills; and (5) internet content creation skills. The indicators are further lowered into statement items so that an instrument to measure internet skills is obtained, which is equipped with 2 answer choices, namely: yes and no. The instrument was distributed to respondents online through the Google Form service. The instrument was measured statistically using SPSS version 25 to determine its reliability. The test result data is presented in Table 2 .

Table 2. Cronbach's Alpha value on the reliability test using SPSS version 25

\begin{tabular}{|c|c|c|c|}
\hline \multirow[b]{2}{*}{ No } & \multirow{2}{*}{$\begin{array}{l}\text { Internet Skills } \\
\text { Questionnaire }\end{array}$} & \multicolumn{2}{|c|}{ Reliability Statistics } \\
\hline & & $\begin{array}{c}\text { Cronbach's } \\
\text { Alpha }\end{array}$ & $\begin{array}{l}\mathrm{N} \text { of } \\
\text { Items }\end{array}$ \\
\hline 1 & Operational & 0,718 & 20 \\
\hline 2 & Formal & 0,558 & 7 \\
\hline 3 & Informational & 0,780 & 10 \\
\hline 4 & Communicational & 0,589 & 8 \\
\hline 5 & Content Creation & 0,644 & 6 \\
\hline
\end{tabular}

Based on the results of these tests, it was found that the Cronbach's Alpha value on each instrument was greater than 0.5 . That is, the research instrument used is reliable to measure students' internet skills. The collected data were then analyzed statistically. In the case of internet skills, the qualitative description is in accordance with the ideal assessment criteria in Table 3 (Widoyoko, 2012), so that it can be stated the internet skill criteria. Apart from that, the aspects of internet skills were also analyzed statistically for their relationship using SPSS version 25 by following the criteria presented in Table 4.

Table 3. The Ideal Assessment Criteria for Internet Skills

\begin{tabular}{ccc}
\hline No & Score Range & Category \\
\hline 1 & $\mathrm{x}>0,8$ & Very Good \\
2 & $0,6<\mathrm{x} \geq 0,8$ & Good \\
3 & $0,4<\mathrm{x} \geq 0,6$ & Enough \\
4 & $0,2<\mathrm{x} \geq 0,4$ & Less \\
5 & $\mathrm{x}<0,2$ & Poor \\
\hline \multicolumn{3}{c}{${ }^{\text {a. }}$ Sumber: Widoyoko, 2011 }
\end{tabular}

Table 4. Criteria for Assessment of Relationship between 2 Aspects of Internet Skills

\begin{tabular}{ccc}
\hline No & Score Range & Category \\
\hline 1 & $|\mathrm{r}|>0.5$ & High Correlation \\
2 & $0.3<|\mathrm{r}| \leq 0.5$ & Medium Correlation \\
3 & $0.1<|\mathrm{r}| \leq 0.3$ & Low Correlation \\
\hline \multicolumn{3}{c}{ b. Sumber: Cohen, 1988. }
\end{tabular}

\section{Results and Discussion}

\section{A. Comparison of Respondents' Inter-net Skill Levels}

Overall, students' internet skills are presented in Fig. 1. 


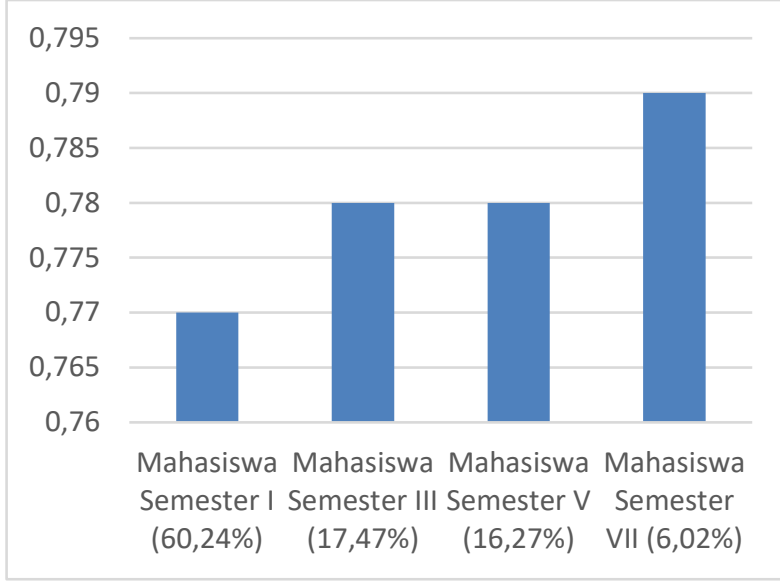

Fig. 1.Distribution of students' internet skills

Based on Fig. 1, the skills of students in semesters $1,3,5$, and 7 are at the same level, namely in the range $0.6-0.8$ with the "Good" category. (Widoyoko, 2012). However, this level of inter-net skills increased slightly as students took education.

\section{B. Comparison of Internet Skill Level in each Aspect}

However, if it is described in more detail, students' internet skills in every aspect vary widely.
That is, the distance between the lowest scores (on the aspect of content creation internet skills) with the highest score (on the aspect of internet communication skills) is quite large presented in Fig. 2.

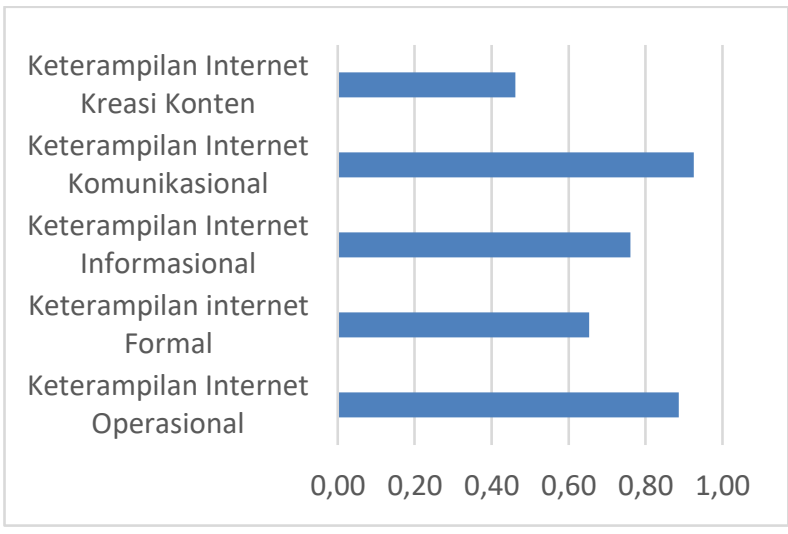

Fig. 2.Distribution of internet skill levels in every aspect

\section{Internet Operational Skills}

In detail, students' internet operational skills can be seen in Table 5 .

Table 5. The score for the assessment of aspects of operational internet skills

\begin{tabular}{|c|c|c|c|c|}
\hline Indicators of Internet Operational Skills & $\begin{array}{c}\text { Skor } \\
\text { Smt. 1 } \\
(60,24 \%)\end{array}$ & $\begin{array}{c}\text { Skor } \\
\text { Smt. 3 } \\
(17,47 \%)\end{array}$ & $\begin{array}{c}\text { Skor } \\
\text { Smt. 5 } \\
(16,27 \%) \\
\end{array}$ & $\begin{array}{c}\text { Skor } \\
\text { Smt. } 7 \\
(6,02 \%)\end{array}$ \\
\hline a. Bookmark a website & $\mathbf{0 , 5 5 *}$ & 0,79 & 0,78 & 0,90 \\
\hline b. Hide pop-ups or ads & $0,43 *$ & 0,62 & 0,59 & 0,60 \\
\hline c. Open a Web address directly without using a search engine like Google. & $\mathbf{0 , 5 6 *}$ & $0,55 *$ & 0,63 & 0,80 \\
\hline
\end{tabular}

c. * Scores are in the range $0.41-0.60$ (in the "Fair" category)

Based on the data in Table 5, operational skills with the lowest score in the category of "Enough", even close to "Poor" are found in the indicators: bookmarking a website; making pop-ups or ads disappear and Opening a Web address rectified without using a search engine like Google.

\section{Formal Internat Skills}

In addition, the students' formal internet skills can be seen in Table 6 . Based on the data in Table 6 , students in the 7th semester have weaknesses in understanding variations in website design and resilience in searching for information online. However, students in other semesters also have skills that are not much different. Informational internet skills in Table 7 shows that students in semesters 1,3 and 5 have difficulties in verifying the information they get online. With these weaknesses, students in the 3rd semester feel the need to take part in training to find reliable information online. In contrast to other online assessment indicators, students' communicational skills have the highest score (Fig. 2). Even so, there were still some assessment items where the score is much lower than the scores on other items, namely: confidence about writing a comment online (Table 8).

Table 6. Score for formal skills assessment

\begin{tabular}{llcccc}
\hline & \multicolumn{1}{c}{ Formal Internet Skills Indicators } & $\begin{array}{c}\text { Skor } \\
\text { Smt. 1 } \\
(\mathbf{6 0 , 2 4 \% )}\end{array}$ & $\begin{array}{c}\text { Skor } \\
\text { Smt. 3 } \\
(\mathbf{1 7 , 4 7 \% )}\end{array}$ & $\begin{array}{c}\text { Skor } \\
\text { Smt. 5 } \\
(\mathbf{1 6 , 2 7 \% )}\end{array}$ & $\begin{array}{c}\text { Skor } \\
\text { Smt. 7 } \\
(\mathbf{6 , 0 2 \% )}\end{array}$ \\
\hline $\begin{array}{l}\text { a. } \\
\text { b. Understand website design variations }\end{array}$ & 0,47 & 0,52 & 0,41 & $\mathbf{0 , 4 0 *}$ \\
& $\begin{array}{l}\text { Resilience in searching for information } \\
\text { online }\end{array}$ & 0,69 & 0,72 & 0,52 & $\mathbf{0 , 4 0 *}$ \\
\hline \multicolumn{5}{c}{ d. * Scores are in the range $0.21-0.40$ (in the "Poor" category) }
\end{tabular}


Table 7. Score of informational skills assessment

\begin{tabular}{|c|c|c|c|c|c|}
\hline & Informational Internet Skills Indicators & $\begin{array}{c}\text { Skor } \\
\text { Smt. 1 } \\
(60.24 \%)\end{array}$ & $\begin{array}{c}\text { Skor } \\
\text { Smt. 3 } \\
(17.47 \%)\end{array}$ & $\begin{array}{c}\text { Skor } \\
\text { Smt. 5 } \\
(\mathbf{1 6 . 2 7 \% )}\end{array}$ & $\begin{array}{c}\text { Skor } \\
\text { Smt. } 7 \\
(6.02 \%)\end{array}$ \\
\hline a. & Reluctance to take courses in seeking information online & 0.49 & 0.31* & 0.63 & 0.90 \\
\hline b. & Verifying information & $0.33^{*}$ & $0.38 *$ & $0.33 *$ & 0.60 \\
\hline
\end{tabular}

e. * Scores are in the range $0.21-0.40$ with a poor category (in the "Less" category)

Table 8. Score of communicational skills assessment

\begin{tabular}{cccccc}
\hline & Skor & Skor & Skor & Skor & Skor \\
Indicators of Communicational Internet Skills & All & Smt. 1 & Smt. 3 & Smt. 5 & Smt. 7 \\
$(\mathbf{1 0 0 \% )}$ & $(\mathbf{6 0 . 2 4 \% )})$ & $(\mathbf{1 7 . 4 7 \% )})$ & $(\mathbf{1 6 . 2 7 \% )}$ & $(\mathbf{6 . 0 2 \% )}$ \\
\hline Confidence about writing comments online & 0.66 & 0.74 & $\mathbf{0 . 5 5 *}$ & $\mathbf{0 . 5 6 *}$ & $\mathbf{0 . 5 0 *}$ \\
\hline f.* Scores are in the range $0.41-0.60$ (in the "Fair" category &
\end{tabular}

f. * Scores are in the range $0.41-0.60$ (in the "Fair" category

\section{E. Internet Content Creation Skills}

Conversely, student content creation skills are inversely related to the communicational skills that these skills have the lowest score. In fact, the skills of these students were classified as very lacking in the assessment items on how to design a website (presented in Table 9).

Table 9. Score of content creation skills assessment

\begin{tabular}{|c|c|c|c|c|c|}
\hline & Internet Skills Assessment Indicators & $\begin{array}{c}\text { Skor } \\
\text { Smt. 1 } \\
(60.24 \%) \\
\end{array}$ & $\begin{array}{c}\text { Skor } \\
\text { Smt. } 3 \\
(\mathbf{1 7 . 4 7 \% )} \\
\end{array}$ & $\begin{array}{c}\text { Skor } \\
\text { Smt. 5 } \\
(\mathbf{1 6 . 2 7 \% )} \\
\end{array}$ & $\begin{array}{c}\text { Skor } \\
\text { Smt. } 7 \\
(6.02 \%) \\
\end{array}$ \\
\hline a. & Beliefs about putting created video content online & $0.25 * *$ & 0.48 & 0.26 & 0.40 \\
\hline b. & Website designing & $0.13 *$ & $0.28 * *$ & $0.26 * *$ & $0.30 * *$ \\
\hline c. & An understanding of the types of licenses that are applied to online content & $0.33 * *$ & $0.31 * *$ & $0.26 * *$ & $0.40 * *$ \\
\hline
\end{tabular}

g. * The lowest score is in the range $0-0.20$ (in the "Very Poor" category)

h. ** Scores are in the range $0.21-0.40$ (in the "Poor" category

\section{F. The Relationship between the Aspects of Internet Skills}

Based on Table 10, the Sig. (2-tailed) between operational skills and content creation of 0.000 (less than 0.05 ). Thus, it can be stated that the two variables have a significant relationship. This condition is also found in the formal and informational skills variable with the Sig. (2-tailed) of 0.003 , on the informational and communicational skills variable with the Sig. (2-tailed) is 0.036, and the communicational variable and content creation with the Sig. (2-tailed) of 0,000 . The rest, the research variables do not have a significant relationship. Despite this, the value of Correlation. The coefficient between operational skills and content creation and communicational skills with content creation ranges from $0.3-0.5$. This shows that the research variables have a moderate correlation with one another (Cohen, 1988). Meanwhile, other variables that have a relationship are at a small correlation level. Based on the Correlation Coefficient value, where all scores on the related variables are valuable; it can be stated that these variables have a positive relationship. This means that if one of the variables increases, the other related variables will also increase linearly. The discussion in this study, the background of the research is the im portance of knowing students' internet skills in the digital era. These skills should have been mastered by students considering that all types of data, information or course materials can be obtained online using internet access either through mobile phones or computers through blended learning. Moreover, the use of digital technology has made terms such as IT, ICT and computer literacy become commonplace for students today (Bawden, 2008). However, it is necessary to conduct a study to ascertain whether all students already have adequate internet skills. Thus, if there is a weakness in the student's internet skills, it can be immediately handled so that the blended learning activity can run optimally.

Before data collection was carried out, the researcher developed a reliable instrument to measure students' internet skills. The instrument developed consists of 5 aspects of assessment, namely: operational internet skills, which contain 20 items, formal internet skills, which contain 7 items, informational internet skills, which contain 10 items, communicational internet skills, which contain 8 items, and internet skills. The instruments were then distributed to 100 participants. The data obtained were tested statistically to determine the reliability of the instrument. Based on the results of statistical tests, the Cron- 
bach's Alpha value in each aspect of the assessment was greater than 0.5 . This shows that the instrument developed is reliable to measure students' internet skills.

Table 10. The results of the correlations test with SPSS version 25

\begin{tabular}{|c|c|c|c|c|c|c|c|}
\hline \multicolumn{8}{|c|}{ Correlations } \\
\hline & & & Operasional & Formal & Informational & Communicational & $\begin{array}{l}\text { Content } \\
\text { Creation }\end{array}$ \\
\hline \multirow[t]{15}{*}{$\begin{array}{c}\text { Kendall's } \\
\text { tau_b }\end{array}$} & Operasional & $\begin{array}{c}\text { Correlation } \\
\text { Co. }\end{array}$ & 1.000 & & & & \\
\hline & & $\begin{array}{l}\text { Sig. (2- } \\
\text { tailed) }\end{array}$ & . & & & & \\
\hline & & $\mathrm{N}$ & 166 & & & & \\
\hline & Formal & $\begin{array}{c}\text { Correlation } \\
\text { Co. }\end{array}$ & -.053 & 1.000 & & & \\
\hline & & $\begin{array}{l}\text { Sig. (2- } \\
\text { tailed) }\end{array}$ & .376 & & & & \\
\hline & & $\mathrm{N}$ & 166 & 166 & & & \\
\hline & Informational & $\begin{array}{c}\text { Correlation } \\
\text { Co. }\end{array}$ & .038 & $.184^{* *}$ & 1.000 & & \\
\hline & & $\begin{array}{l}\text { Sig. (2- } \\
\text { tailed) }\end{array}$ & .542 & .003 & . & & \\
\hline & & $\mathrm{N}$ & 166 & 166 & 166 & & \\
\hline & Communicational & $\begin{array}{c}\text { Correlation } \\
\text { Co. }\end{array}$ & .119 & -.074 & $.143^{*}$ & 1.000 & \\
\hline & & $\begin{array}{l}\text { Sig. (2- } \\
\text { tailed) }\end{array}$ & .072 & .269 & .036 & . & \\
\hline & & $\mathrm{N}$ & 166 & 166 & 166 & 166 & \\
\hline & Content Creation & $\begin{array}{c}\text { Correlation } \\
\text { Co. }\end{array}$ & $.373^{* *}$ & -.012 & .080 & $.307^{* *}$ & 1.000 \\
\hline & & $\begin{array}{l}\text { Sig. (2- } \\
\text { tailed) }\end{array}$ & .000 & .839 & .200 & .000 & . \\
\hline & & $\mathrm{N}$ & 166 & 166 & 166 & 166 & 166 \\
\hline
\end{tabular}

Before data collection was carried out, the researcher developed a reliable instrument to measure students' internet skills. The instrument developed consists of 5 aspects of assessment, namely: operational internet skills, which contain 20 items, formal internet skills, which contain 7 items, informational internet skills, which contain 10 items, communicational internet skills, which contain 8 items, and internet skills. The instruments were then distributed to 100 participants. The data obtained were tested statistically to determine the reliability of the instrument. Based on the results of statistical tests, the Cronbach's Alpha value in each aspect of the assessment was greater than 0.5 . This shows that the instrument developed is reliable to measure students' internet skills.

Instruments that have been declared reliable are then distributed online via Google Form to students in each batch (Semester I, III, V and VII). Of the total students, only 166 people responded to the given instrument. Based on the results of data analysis, students' communication internet skills are at the highest level with the very good category. (Widoyoko, 2012). Thus, students are very skilled in communi cating in cyberspace. This is reflected in the behavior of students in communicating. The student knows the exact time and which information to share online. In addition, they also know who they should discuss further regarding the content presented. This is reasonable considering that gadgets, one of which is a smartphone, are a basic need for students.

Students can easily use it to communicate information and ideas effectively to many audiences using a variety of media formats online (Claro et al., 2012; Siddiq et al., 2016) through social media. Plus, there are many choices of social media applications that can be used to communicate with other people in cyberspace. These applications also offer features that are attractive and easy to use. Thus, students as users can operate social media applications in a short time (Ng, 2012; Van Deursen et al., 2016). Therefore, the practicality of using the application allows the students' operational internet skills to fall into the good category.

Moreover, the lecture system implemented in the faculty environment has been encouraged to be conducted online (Blended Learning). This requires students to have good operational internet skills to be 
able to attend lectures well. In addition, the use of packages in surfing requires students to get free internet access via Wi-Fi provided by educational institutions. It is not enough to finish here, in completing lecture assignments or just deepening the understanding of the course material, students' skills in browsing, googling, downloading, uploading, bookmarking, and all other internet activities without immediately increase even without special training or education provided.

Even so, they agreed that careful behavior in cyberspace was needed, especially in terms of commenting. The skill item shows full value, among other assessment items. This considers that it is often found in communication on social media that there are endless conflicts beginning with extreme or ambiguous comments. This is a sign that students involve not only communication skills but also emotional skills in interacting on social media (Calvani et al., 2012; Helsper \& Eynon, 2013; Jenkins, 2009; Litt, 2013; Van Deursen et al., 2014; Van Deursen \& Van Dijk, 2009). Thus, they need to be careful in expressing their opinion. This caution can be seen indirectly from other assessment items on the communicational aspect, where almost 50\% of students who gave responses felt unsure about writing comments in social media. This uncertainty arises because students do not know for sure who they are communicating with or sharing information with. Even when it is confirmed that the information provided is legally correct, there is sometimes still heated debate. This is because in cyberspace there are various kinds of characteristics of the interlocutor.

Therefore, students need to make sure the information they share is correct so that there is no conflict in communication in cyberspace. To ensure informative data, students in this study were already at a good level or skilled in sharing or receiving information. Students can use strategies to clarify information obtained previously shared with others. The strategy is carried out by comparing the same information on several websites (Ahmad et al., 2013; Snow \& Katz, 2010). In addition, students can also evaluate whether the website that shares the information or sources is trustworthy or not. With this reliable information, students can understand the content more deeply provided. This allows students to think further based on the correct data so that students have the strength to walk on the right track.

High communicational internet skills are apparently not accompanied by content creative internet skills, which are part of digital competence (Ferrari, 2012). These students tend to be categorized as a consumptive group. This is based on data on students' internet skills, content creation at the lowest level, among other skills. This shows that students prefer to use existing products to support their communication activities compared to their desire to create similar products that are more attractive. In fact, in the world of work, after completing education. They are more required to be able to create or develop something new. In the case of the scientific fields they study, they are required to be able to develop attractive learning designs. Moreover, each region where they come from has its own characteristics. By having internet content creation skills in developing content to be shared online, they will provide interesting information and may be a source of inspiration for others.

Furthermore, in relation to the relationship between these variables, operational skills and communicational skills have a moderate (moderate) relationship to content creation skills. The consideration is that to be creative in terms of content, students first need to master skills in operating the internet. When these basic skills can be mastered, students will find it easy to be creative in developing outstanding content. For example, when students receive a learning video. However, the learning video still needs to add captions so that the content in the video becomes clearer, especially for users who can better understand the learning video material in the presence of text. Thus, students need to understand the operational steps to be able to process this. These operational steps need to be mastered first to be creative. As with communicational skills, students who are skilled at communicating have more experience related to interesting content to be discussed in an online environment. Based on these experiences, students have more sources of inspiration to modify creative content using ICT, which is a major component in content creation (Hinrichsen \& Coombs, 2013; Mengual-Andrés et al., 2016). This allows them to become a productive part of a community that is rich in information and technology-based (Ahmad et al., 2013).

Moreover, even at a weak level; there is a relationship between formal and communication with information skills. Communicative students have an extensive network to get information. It also allows them to clarify the information they receive from sources they trust. The relationship between communicational skills and international skills is very important for students to master. It considers that communication is a skill in the 21st Century (Voogt \& Roblin, 2012). With communication, students can multiply factual knowledge so that their data literacy also increases. Communication also provides opportunities for students to get to know the characteristics of the interlocutor. The condition of mutual understanding when communicating is also important, which is a benefit that can be obtained when student 
human literacy develops well. Moreover, ICT facilitates human activities in obtaining informative data. Apart from going through social media to get information directly from the source, students can also search for data or lecture material from recorded sources, both in the form of online news and articles in journals; through the website."

\section{Conclusion}

Based on the research data, it can be concluded that students have good internet skills, including operational, formal, communicational, and informational internet skills. However, student content creation internet skills are still low. In addition, there is a positive relationship between operational and communicational skills and content creation skills. Thus, students in this study have good basic internet skills. In accordance with the conclusion, further research is needed to develop creative skills so that students are even more productive in creating or developing content in a digital environment).

\section{References}

Ahmad, M., Karim, A. A., Din, R., \& Albakri, I. S. M. A. (2013). Assessing ICT competencies among postgraduate students based on the 21st century ICT competency model. Asian Social Science, 9 (16), 32.

Alkali, Y. E., \& Amichai-Hamburger, Y. (2004). Experiments in digital literacy. CyberPsychology \& Behavior, 7(4), 421-429.

Bawden, D. (2008). Origins and concepts of digital literacy. Digital Literacies: Concepts, Policies and Practices, 30 (2008), 17-32.

Brandtweiner, R., Donat, E., \& Kerschbaum, J. (2010). How to become a sophisticated user: A twodimensional approach to e-literacy. New Media \& Society, 12(5), 813-833.

Bunz, U., Curry, C., \& Voon, W. (2007). Perceived versus actual computer-email-web fluency. Computers in Human Behavior, 23(5), 2321-2344.

Calvani, A., Fini, A., Ranieri, M., \& Picci, P. (2012). Are young generations in secondary school digitally competent? A study on Italian teenagers. Computers \& Education, 58(2), 797-807.

Claro, M., Preiss, D. D., San MartîN, E., Jara, I., Hinostroza, J. E., Valenzuela, S., \& Nussbaum, M. (2012). Assessment of 21st century ICT skills in Chile: Test design and results from high school level students. Computers \& Education, 59(3), 1042-1053. https://doi.org/http://dx.doi.org/10.1016/j.compedu. 2012.04.004.

Cohen, J. (1988). Statistical power analysis for the behavioral sciences, 2nd edn. Á/L. Erbaum Press, Hillsdale.

Ferrari, A. (2012). Digital competence in practice: An analysis of frameworks. In Sevilla: JRC IPTS. https://doi.org/(DOI: 10.2791/82116)
Hargittai, E., \& Hsieh, Y. P. (2012). Succinct survey measures of web-use skills. Social Science Computer Review, 30(1), 95-107.

Haythornthwaite, C. (2007). Social networks and online community. In The Oxford handbook of Internet psychology (9th ed.). Oxford University Press.

Helsper, E. J., \& Eynon, R. (2013). Distinct skill pathways to digital engagement. European Journal of Communication, 28(6), 696-713.

Hinrichsen, J., \& Coombs, A. (2013). The five resources of critical digital literacy: a framework for curriculum integration. Research in Learning Technology, 21(21334), 1-16.

Jenkins, H. (2009). Confronting the challenges of participatory culture: Media education for the 21st century. The MIT Press.

Krueger, B. S. (2006). A comparison of conventional and Internet political mobilization. American Politics Research, 34(6), 759-776.

Kuntarto, E. (2017). Keefektifan model pembelajaran daring dalam perkuliahan Bahasa Indonesia di perguruan tinggi. Indonesian Language Education and Literature, 3(1), 99-110.

Litt, E. (2013). Measuring users' internet skills: A review of past assessments and a look toward the future. New Media \& Society, 15(4), 612-630.

Mengual-Andrés, S., Roig-Vila, R., \& Mira, J. B. (2016). Delphi study for the design and validation of a questionnaire about digital competences in higher education. International Journal of Educational Technology in Higher Education, 13(1), 12.

$\mathrm{Ng}$, W. (2012). Can we teach digital natives digital literacy? Computers \& Education, 59(3), 10651078.

Potosky, D. (2007). The Internet knowledge (iKnow) measure. Computers in Human Behavior, 23(6), 2760-2777.

Siddiq, F., Scherer, R., \& Tondeur, J. (2016). Teachers' emphasis on developing students' digital information and communication skills (Teddics): A new construct in 21st century education. Computers \& Education, 92(January-February), 1-14.

Snow, E., \& Katz, I. (2010). Using cognitive interviews and student response processes to validate an interpretive argument for the ETS iSkills ${ }^{\mathrm{TM}}$ assessment. Communications in Information Literacy, $3(2), 98-127$.

Van Deursen, A. J., Courtois, C., \& van Dijk, J. A. (2014). Internet skills, sources of support, and benefiting from Internet use. International Journal of HumanComputer Interaction, 30(4), 278-290.

Van Deursen, A. J., Helsper, E. J., \& Eynon, R. (2016). Development and validation of the Internet Skills Scale (ISS). Information, Communication \& Society, 19(6), 804-823.

Van Deursen, A. J., \& Van Dijk, J. A. (2009). Using the Internet: Skill related problems in users' online behavior. Interacting with Computers, 21(5-6), 393-402. 
Voogt, J., \& Roblin, N. P. (2012). A comparative analysis of international frameworks for 21st century competences: Implications for national curriculum policies. Journal of Curriculum Studies, 44(3), 299-321.
Widoyoko, E. P. (2012). Teknik penyusunan instrumen penelitian (Vol. 15). Pustaka Pelajar.

Žukauskas, P., Vveinhardt, J., \& Andriukaitienè, R. (2018). Management culture and corporate social responsibility. BoD-Books on Demand. 